\title{
Neoconservatism and American Foreign Policy
}

\author{
Stephen McGlinchey ${ }^{1}$, Cardiff University, United Kingdom \\ [McGlincheyST@cf.ac.uk]
}

\begin{abstract}
Neoconservatism has been clearly visible in domestic American politics since the late $1960 s$, though it has only come to the fore internationally in recent years due to the heavily neoconservative influenced direction of the Bush administration in its formative years after 9/11, principally through its prosecution of its War on Terror and via the rhetoric of the President himself. As a much misunderstood term, subject to media jingoism and heated partisan rhetoric in every corner of the globe, this article establishes exactly what neoconservatism is in relation to foreign policy via a reading of key neoconservative literature and corresponding critiques. Subsequently, using the Bush administration as an example, the article evaluates how neoconservative foreign policy postulates are transferred into reality during the War on Terror. Finally the analysis reaches beyond the Bush administration establishing whether a neoconservative legacy remains active in the present day under the Obama administration.
\end{abstract}

Keywords: Neoconservatism - War on Terror - Bush Doctrine - American Foreign Policy - Neoconservative Legacy

$\mathrm{N}$ eoconservatism is something of a chimera in modern politics. For its opponents it is a distinct political movement which emphasizes the blending of military power with Wilsonian idealism (Mearsheimer 2005), yet for its supporters it is more of a 'persuasion' that individuals of many types drift into and out of (Kristol 1995, ix). Regardless of which explanation is more correct than the other, it is now widely accepted that the neoconservative impulse has been visible in modern American foreign policy, particularly within the George W. Bush administration, and that it has left a distinct impact. This article will first explore the neoconservative ideology as it applies to foreign policy, establishing the domestic foundations on which it was built. Secondly, examples of the implementation of neoconservative ideas into reality will then be analysed, most notably through the examination of the War on Terror, and the relationship between America and Israel. Finally, the article will assess whether after a change of administration in 2009, any of the neoconservative legacy remains alive in American politics.

\footnotetext{
${ }^{1}$ The author wishes to express thanks for the perceptive comments made on the first draft of this article by the two anonymous reviewers.
} 
Neoconservatism became a distinct ideology, or persuasion, in the aftermath of the cultural unrest and university riots in the United States during the late 1960s. A group of largely working class Jewish American intellectuals based in New York, most notably Irving Kristol, interpreted the situation at the time as modern liberalism attacking its own foundations and moral integrity in favour of mass social revisionism. In Kristol's own words:

"Liberals were wrong, liberals are wrong, because they are liberals. What is wrong with liberalism is liberalism - a metaphysics and a mythology that is woefully blind to human and political reality" (Murray 2005, 45).

For Kristol, then, reality was such that mankind was naturally evil. Socialism had failed, so the solution was the pursuit of a non secular liberal democracy that addressed the crisis of relativism (Murray 2005, 46-47). To paraphrase Allan Bloom, American minds had become so open that they had become closed (Bloom 1987, 337-339). The early neoconservatives sought to reorient the United States domestic politics by harnessing the readymade moral foundations that religion provided, without necessarily being religious themselves, and mould that together with Platonist ideology via the reading provided by Leo Strauss. Indeed Strauss is often cited as the ideological father of neoconservatism, although within the persuasion his influence is often downplayed (Murray 2005, 37). The use of religion was simply due to the fact that the Judeo-Christian moral package provided a clear sense of right and wrong that could be harnessed. Finding morality through secularist ideals would lead to moral bankruptcy, crime and underachievement (Kristol 1995, 365). In the true Platonic sense, the neoconservatives had realised what was best for America and they felt it their duty to steer the misguided populace, and later the world via neoconservative application in foreign policy, to their senses.

Having found an identity in the domestic political sphere, foreign policy postulates followed. Irving Kristol describes three central pillars: a strong idea of patriotism, a round rejection of anything resembling or pointing towards a world government, including round rejection of the United Nations and NATO - which were "on their way to becoming moribund" (Kristol 2003, 367), and finally the view that statesmen should clearly distinguish friends from enemies (Kristol 2003, 2). These pillars are fused with a strong Manichean morality that compels America to use its power for the common good rather than reserve it. This would become viscerally clear in Bush's War on Terror, but it can be identified as far back as in the early Reagan and late Carter administrations according to Francis Fukuyama (2006, 45). In direct opposition to the timely practice of realpolitik in foreign affairs, the foreign policy of a country must represent its internal moral character. Maintaining alliances with dictators and unfavourable regimes is therefore abhorrent to neoconservatism. Therefore, American power has been and could be used for 'moral' purposes. Iraq is the stock example in the contemporary era and highlights clearly through the practice of regime change and democratisation, aided by interventionist military force, how neoconservatism applies to modern foreign policy. Neoconservatism holds the domestic and international sphere to a clear moral and ideological standard and champions the use of militarism to further that standard globally. It does not ignore soft power issues, but rather, "when your only tool is a hammer, all problems look like nails" (Fukuyama 2006, 63). Put more plainly, "the world is adrift, and for our safety it needs to be moored" (Murray 2005, 55). At the turn of the century Neoconservatives believed that they alone possessed the moral and ideological 
foundations to successfully direct international relations towards the benefit of all and that the United States was blessed with the unique opportunity to prosecute such an endeavour:

"Americans should understand that their support for American pre-eminence is as much a strike for international justice as any people is capable of making" (Kagan \& Kristol 20oo, 24).

In the post Cold War era, neoconservatism identifies closely with The End of History? thesis (Fukuyama 1989). This presupposes that liberal democracy will spread globally in the wake of the West emerging triumphant in the Cold War, rendering all opposing political orientations obsolete. The support for democratisation and the spread of liberal institutions into non Western areas seems fairly conventional when applied alongside Kantian cosmopolitanism and Doyle's 'democratic peace thesis', however it obtains its distinctive neoconservative flavour when the use of interventionist military policies to affect democratisation of a certain target nation are used to affect and artificially accelerate that process. Indeed, it is the application of this strategy that has caused mass critique of the Bush foreign policy package in the post September 11 world. In 2006, writing on the War on Terror which he describes as "predominantly shaped by neoconservatives" (2006, 3), Francis Fukuyama abandoned his neoconservative persuasion and condemned the use of morality and ideology in foreign policy precisely because America has no remaining moral credibility in the Middle East as a result of past and present actions $(2006,187)$. That lack of credibility has demonstrably lowered American international standing and led to suspicion that the democratisation efforts are a veil for imperialism and a means to control access to the oil reserves of the Middle East, representing an essentially unchanged regional policy from that of the Cold War era. As the idea of democratisation has both predated and survived the neoconservative era of the Bush administration, justifiable suspicion remains regarding its legitimacy now that it has been tainted with the fallout from the War on Terror through its faltering applications in Afghanistan and Iraq.

THE NEOCONSERVATIVE 'WAR ON TERROR'

The events of September 11 provided the opportunity for those with a neoconservative persuasion to gain prominence in the Bush administration as they were able to offer a readymade logic with which to view the new post 9/11 era and could point to a legacy of literature and. For much of the 1990s, neoconservative literature was expanding in opposition to the New World Order of peace, offering the view that this peace was deceptive. It thus claimed that America should use The Unipolar Moment (Krauthammer 1990) to create a unipolar era of unrivalled American power projected globally (Kagan 2002, 136138). This school of thought, although a seemingly marginal position, is validated at least in part by many leading neo-liberal academics. John Ikenberry acknowledged that the global order is an American System based on the proviso that "the United States makes its power safe for the world and in return the world agrees to live within the American system" (Ikenberry 2001, 21). Krauthammer describes the American system more vividly: "unashamedly laying down the rules of world order and being prepared to enforce them" (Krauthammer 1990, 33). Both express no desire for this to change, but Ikenberry does contemplate the potential danger of the overzealous projection of American power recognising that "all this could go sour" (Ikenberry 2001, 31). The souring of this system is the moving away from the multilateral and inclusive posture of the elder Bush (Bush 1) and Clinton administrations towards the unilateral flavoured and confrontational nature of the George W. Bush administration. 
To depart momentarily into International Relations semantics, Michael Lind emphasizes the difference between neoliberal institutionalism - within which he situates Ikenberry and former President Bill Clinton, and neoliberal internationalism. Neoliberal internationalism is, in Lind's description, an evolution of the Roosevelt tradition of self determination and non aggression as the bedrock of international affairs - a similar view to the one upheld by George H. W. Bush. Human Rights, global market liberalisation, and democratisation; all wedded to neoliberal institutionalism. They are loftier goals "which should all be promoted by exhortation rather than coercion" (Lind 2006). There is no need to resort to conceptual stretching to identify here a similarity between neoliberal institutionalism and neoconservatism. Both point towards American global hegemony, albeit in different ways. Lind makes this point in expressing that the only difference between the two is that neoliberals are dishonest about admitting their intentions for American power, whilst neoconservatives are open about it. The divergence is over what kind of empire America should have; one disguised through using multilateral institutions and soft power to hide the true reality of American global domination, or a global empire backed by the open use of hard power and unilateralism. Nevertheless, both end goals are in fact similar, which again raises concerns over the true legitimacy of such currently active American foreign policy goals as democratisation. Lind's position is an interesting nuance, and one that suggests that there is much more of a logical flow from Clinton to Bush in their approach to foreign policy, despite the perceived change in structure after 9/11.

Neoconservatives lamented the Clinton years as a period in which America did not capitalise on a once in a lifetime chance to cement its leading position in the world while it stood without any serious competitor. Colin Powell, for example, condemned the Clinton foreign policy decision making process as no more than "a coffee house chatting session" with no dominant voice propelling it (Brzezinski 2007, 87). The fundamental blow that 9/11 struck to the national consciousness was an opportunity to push for a new direction for America and awaken the political establishment from its post Cold War slumber. Quickly after 9/11 President Bush became a convert to the neoconservative persuasion, something clearly visible in his West Point speech of 2002, and even more so in the 2002 National Security Strategy. Both publicly outlined the new Bush foreign policy direction and re-introduced neoconservatism to mainstream American foreign policy. At West Point, Bush made the seminal remark:

"We cannot put our faith in the word of tyrants, who solemnly sign non-proliferation treaties, and then systematically break them. If we wait for threats to fully materialize, we will have waited too long" (Bush 2002).

This statement introduced the policy of preemptive force as a proactive feature of American foreign policy although in both its subsequent use and its description, it was more correctly a policy of preventive force - which is a degree of magnitude above preemption and holds greater implications for the structure of the international system, and via international law is widely interpreted as illegal. Later in the same speech, Bush invokes an extreme moral absolutism:

"Some worry that it is somehow undiplomatic or impolite to speak the language of right and wrong. I disagree. Different circumstances require different methods, but not different moralities. Moral truth is the same in every culture, in every time, and in every place" (Bush 2002).

Binding the idea of a moral purpose to foreign policy is not unusual in American politics. However, using it so prominently to define the emerging War on Terror, taken 
together with Bush's public disregard for multilateral institutions and his unilateral posture, is without doubt inspired if not directly underwritten by a significant dose of neoconservatism.

Combining the neoconservative persuasion and the Bush administration's policies further, the 2002 National Security Strategy stated that "the war... is a global enterprise of uncertain duration" (The National Security Strategy of the United States of America (NSS) 2002, iii) and that "the only path to peace and security is the path of action" (NSS 2002, IV). In the 2006 NSS, President Bush continued the neoconservative rhetoric despite ongoing difficulty and loss of support in Iraq stating that America has chosen "leadership over isolationism" and endeavours to "shape the world, not merely be shaped by it" (NSS 2006, iii). Much was made of a supposed 'return to realism' from 2006 onwards, most notably watermarked by the departure of Donald Rumsfeld from the Pentagon. However, despite a generally more nuanced rhetoric from the White House owing to increased domestic opposition, falling approval ratings and the Iraq quagmire, the general thrust of the foreign policy package was retained. Additionally, the 2006 NSS document did not simply repeat the vague and generalistic language of the 2002 documents but contained clear and specific threats to 'rogue states' such as Iran. Furthermore, it maintained the provision to extend the use of preventive military action.

\section{NEOCONSERVATISM AND ISLAM}

In order to understand the neoconservative focus on the Middle East at the expense of other geo-political theatres, and to explain the receptiveness of George W. Bush to their persuasion, an examination of the controversial works of two academics is necessary: Bernard Lewis and Samuel Huntington. Lewis, a neoconservative, was received at the White House by Karl Rove in November 2001 in order to discuss the subject of his thesis which states that as the current Middle Eastern status quo was created by 'Imperial partition' drawn over and through ancient civilisations, there is a legacy of instability in the region (Lewis 2004, 417). He therefore asserts that this unresolved clash of identities must be addressed as a priority as there are only two possible solutions to the ongoing instability of the region: either Islam or democracy (Lewis 2004, 423). Islam, with its own unique set of legal principles enshrined in Sharia Law is at odds with liberal democracy and, according to Lewis's reading, is therefore mutually exclusive and incompatible. Conflict is therefore inevitable. The established contemporary American position towards the Middle East was primarily status quo oriented. Iraq's advance into Kuwait was repelled but no regime change was attempted; it resulted in the Gulf War doing no more than restoring the status quo. Clinton's whole approach to Iran and Iraq was based on containment and sanctions, not regime change - again perpetuating the status quo. If Lewis's controversial thesis was correct, these policies were enabling a ticking time bomb to threaten America.

Following on, Huntington, who is not a neoconservative, borrows the words of Hedley Bull who stated that the West's 'apogee' was 1900. Since then it has been slowly declining in stature and influence. Bull predicted that as Europe declined after the major World Wars, America would follow suit in the near future as part of a larger inevitable process of rebalancing internationally (Huntington 1997, 83). Huntington wants to categorically dismiss the validity of the neoliberal 'End of History' argument by re-emphasising the possible decline of the West in line with Bull's prediction. In Huntington's eyes a determined 
opposition by the other civilisation groupings, most notably those connected with Islam, in a fight for the survival of their (incompatible) way of life through a clash of civilisations is possible - as is the mirrored possibility of a pre-emptive fight by the 'West' to halt their own decline. The author thereby develops Lewis's thesis of a future run either by democracy, or Islam. It is not a wild leap to view the War on Terror as symptomatic of this as viewed from both sides of the fence. This helps to understand why the views expressed in the neoconservative literature thus far analysed that advocated the need for American dominance and unrivalled strength were seen as necessary, and seen as all the more urgent after 9/11. From this perspective, American policy towards the Middle East would have to change significantly, and it did.

Iran is the only logical candidate for a leader of such a theoretical 'Islamic force' to oppose the 'West'. A nuclear armed Iran would make that threat more alarming; and given the blurring of the lines between proliferation, state sponsored terrorism, and the rise in religious extremism in the post 9/11 era, Iran would become an existential threat for the United States and its designs for the Middle East. Of course this train of thought grossly underestimates the deep divisions in the Islamic world, prominently the Shi'a composition of Iran (as opposed to the vast majority of Muslims belonging to the Sunni branch of Islam) and their predominantly Persian rather than Arab ethnicity. Nevertheless, Norman Podhoretz insists that America must take military action to end Iran's nuclear programme. This is necessary as September $\mathbf{1 1}^{\text {th }}$ marked the beginning of World War IV (the Cold War being the third) and Islamofascism is merely the most recent mutation of the totalitarian disease that has plagued the Twentieth Century (Podhoretz 2007, 17). America must destroy Iran to stop it creating an "Islamofascist" world order (Podhoretz 2007, 20). Extreme as it is, this sentiment was directly voiced by Bush in 2005:

"The militants believe that controlling one country will rally the Muslim masses, enabling them to overthrow all moderate governments in the region and establish a radical Islamic empire that spans from Spain to Indonesia”

That Islamic Empire, an Islamic Caliphate, dedicated to bringing Islamic law and teachings to the entire world, is the manifestation of the fears of Podhoretz. It precisely underlines the extremity of the neoconservative world view, the reason for the focus on the Middle East, and the significant departure neoconservative doctrine represents from the traditional liberal and realist dichotomy in foreign policy.

John Ikenberry offers an extensive critique of neoconservatism, noting that far from creating a unipolar era, it experienced only a 'moment' in the limelight before failing visibly in 2004. For Ikenberry, Iraq was a geostrategic failure; the ideology of the War on Terror was unsustainable politically and financially; American military might had been miscalculated; unipolarity is not legitimate when weighed against multipolarity, nor is preemption; and the neoconservative ideology is unstable, crude and ethnocentric (Ikenberry 2004, 8-19). Ikenberry derides the persuasion as fundamentalist stating conclusively that "their history is defective, their policies ineffective" (Ikenberry 2004, 20). This rejection is derived from a reading that places high credence in the two 'grand bargains' of the global system: the realist idea of security and stability, and the liberal institutionalism that tempers that realism. This duopoly makes American power safe for the world (in theory), and it is through the upsetting of this delicate balance that the neoconservative persuasion of the Bush Presidency has not only highlighted the illegitimacy of that persuasion through its actions, but perhaps

${ }^{2}$ http://news.bbc.co.uk/1/low/world/americas/4316698.stm 
irreparably damaged faith in the entire system (Ikenberry 2001, 19-22). The neoconservatives themselves do not believe they are fundamentalists per se, but rather that they observe a danger that others ignore:

"Events of recent years have given us no reason to change our fundamental view either of the emerging dangers or of the prescriptions for meeting those dangers. If anything, the trend of the past few years has proven more troubling than we anticipated" (Kagan 200o, vii).

The realist critique of the neoconservative doctrine in foreign policy is perhaps the most persuasive one. John Mearsheimer offers a similar critique of the legitimacy of neoconservatism to Ikenberry, but contextualises his dissent:

"The dispute about whether to go to war in Iraq was between two competing theories of international politics: realism and the neoconservatism that underpins the Bush doctrine" (Mearsheimer 2005).

Rather than simply stating that neoconservatism underpins the Bush doctrine, he goes on to assert that both are essentially the same thing: a merger of idealism and power in foreign affairs described as "Wilsonianism with teeth" (Mearsheimer 2005). He accuses the Bush doctrine of presuming that the preemptive exercise of American power will produce a domino effect persuading other nations such as Iran to surrender to America's will, when in fact timely honoured realist thinking has shown that the likely outcome would rather be a militarization of said nations to protect their sovereignty and attempt to balance American power (Mearsheimer 2005). In this instance, the realist critique of neoconservative foreign policy has so far proven incredibly accurate as Iran actively continues to develop nuclear technology and adopts an increasingly belligerent posture towards America and Israel. Iraq and Afghanistan are now arguably failed states and terrorism and violence in the region has escalated dramatically as an advertisement from the op-ed page of the New York Times on 26 September 2002 predicted in advance. This was signed by 33 scholars of international relations including Kenneth Waltz and John Mearsheimer. Developing the critique further, the Wilsonian core of the neoconservative ideology, enshrined in democracy promotion as a foreign policy tool, is cited as an ambitious failure: "this was to be social engineering on a massive scale and it was to be done with a mailed fist" (Mearsheimer 2005).

The failure was in overlooking the important realist postulate that to citizens of any nation, nationalism and sovereignty are more powerful and carnal than loftier ideas of democracy. Hence, it is entirely inkeeping with realpolitik to view the Iranian quest to develop an independent nuclear deterrent as a rational choice in line with seeking a credible deterrence from American or Israeli militarily-enforced regime change. Hence, the entire episode of neoconservatism as applied to the Middle East can be validly read as a self fulfilling prophecy.

Even those within the neoconservative persuasion who accept that the exercise of neoconservative foreign policy has not heralded the intended results plead for its continuation, to finish the job, so that the rest of the world can look back in posterity and see that they were right. The legitimacy of that point of view, as expressed most passionately by Podhoretz through his pleas to bomb Iran and enact a regime change strategy there to jump start the democracy domino in the Middle East, remains to be seen - and remains vocally active even in the Obama era. It is impossible to predict the future; even realism could not do that in the case of the sudden ending of the Cold War. However, realism survived that failure and perhaps neoconservatism will survive the apparent failure amongst popular consensus. 
Whilst not wishing to roundly condemn neoconservative postulates, taken at face value as those postulates were in the Bush administration, it certainly seems a very hard case to answer for. The Iraq quagmire was forewarned by the 33 scholars, yet it was pursued. The failure of the democratisation domino effect was widely predicted, yet Afghanistan and Iraq linger in a worse state than prior to invasion and the Middle East is experiencing growing anti-Americanism and increased terrorism in countries such as Pakistan. The core neoconservative tenet of distinguishing friends from enemies and the 'with us or against us' rhetoric that followed from it throughout the Bush administration has stretched the alliance with traditional allies in the European Union and, as Ikenberry points out, damaged the delicate grand bargain of American power tempered with multilateral legitimacy. Such damage has been actively acknowledged by the Obama administration as from day one it sought to roll back to a more multilateral, inclusive and diplomatic position internationally, more in line with the American position professed by Ikenberry. Obama even won a Nobel Peace Prize for his initial efforts, which was no doubt a political seal of approval for the anticipated end of the Bush era of unilateralism. However in reality, the changes have turned out to be much more subtle.

THE ISRAEL FACTOR IN NEOCONSERVATISM

The core postulate of Bush's neoconservative foreign policy package, revolutionary democratisation, is intricately tied to Israel's security. Israeli politicians have long stressed that they live in a 'tough neighbourhood' and frequently stake their claim to be the only truly democratic nation in a sea of dictatorships and corrupt regimes. Both the domestic Israel lobby and the Bush administration believed toppling Saddam Hussein would lead to a domino effect of democratisation that would simultaneously fulfil the aims of increasing Israel's security and the wider aims of the Bush doctrine ${ }^{3}$. In that sense, Mearsheimer and Walt (2007) argue that the lobby was the key variable in making the Iraq war happen when it joined the neoconservative chorus.

Where this applies to Iran is ever more important. Mearsheimer and Walt postulate that the lobby was equally as concerned, even as far back as the Clinton years, with Iran. In a pragmatic way the various groups in the lobby understood the neoconservative desire to deal with Iraq first (see Perle 1999), yet read the Bush administration's intent as one of enforcing regime change in Iraq and then Iran in quick succession. Hence the frustration when this did not occur (Mearsheimer \& Walt 2007, 233-234). In reality, Iran provided significant tactical support in the Afghanistan campaign. It offered a significant normalisation dialogue with the United States in the immediate aftermath of the 2003 Iraq invasion, presumably fearing it could be next at a time when American power appeared to be at its zenith. In all cases, the lobby made a "concentrated effort" to spoil the process (Mearsheimer \& Walt 2007, 282302). The authors cite a stream of empirical data to demonstrate their thesis and state:

"Israel and the lobby...are the central forces today behind all the talk in the Bush administration and on Capitol Hill about using military force to destroy Iran's nuclear facilities" (Mearsheimer \& Walt 2007, 282).

According to this estimation, the next President in 2009, despite their particular orientation in foreign policy, was just as likely to attack Iran to halt its regional ambitions and remove the threat that poses to Israel, as the lobby will continue to shape policy in that

\footnotetext{
${ }^{3}$ See 'A Clean Break: A New Strategy for Securing the Realm'. Available at: http://www.iasps.org/strat1.htm.
} 
particular direction. Having now witnessed the approach of Obama for some 18 months on Iran, this prediction has been largely proven accurate, at least in rhetoric if not in action. Obama's inauguration year promise to "reach out a hand" to Iran, has been replaced with a reappraisal of the Bush approach4. In addition, the publicly announced statement that the force option is still "on the table" 5 , conciliated by the Iranian steadfast desire to not negotiate with any good faith on making concessions on its nuclear program.

Walter Russell Mead states that the growing power of the lobby is a distortion, and much of the Israel bias in American foreign policy (which he also recognises) is really the result of the significant evangelical rise in American political life. Their desire to fervently support Israel is based on their own convictions derived from their particular reading of the Bible (Mead 2006, 41). Indeed, with Bush's evangelical orientation, Mead's point is well advised. Moving on, Gorenberg notes that the influence of the lobby has been overstated; being correct in the recognition that they attempt to control American policy - as any lobby will naturally do within its sphere of interest - but never really achieves the magnitude of success Mearsheimer and Walt credit them with due to the diverse network of competing and divergent interests on Capitol Hill (Gorenberg 2008, 32). Gorenberg's point is valid in the sense that the lobby and successive Israeli governments have still not received clear US support for their steadfast desire to forcibly and urgently end Iran's nuclear program, which is frequently described as an 'existential threat' to Israel's existence. Finally, the neoconservative publication, Commentary, published a response to Mearsheimer and Walt, rejecting their thesis, stating that it employed anti-Semitic stereotypes and lacked original research, relying instead on secondary sources and crass generalisations (Stephens 2007).

Whilst there is a valid argument to be made that the book does oversimplify and perhaps over-emphasize the role of Israel and the lobby on foreign politics in America, it is a baseless accusation to accuse the authors of anti-Semitism or bad scholarship. The real conflict between the neoconservatives and Mearsheimer and Walt here is most probably based on the fact that both authors are prominent realists. Realists, particularly Mearsheimer, have provided an acute and sustained critique of the whole neoconservative project from the outset. The standard defence of those in the Israel lobby, of which many neoconservatives are closely allied (although not all neoconservatives are Jewish), to anyone accusing them of wielding a disproportionate influence in foreign policy and of acting in interests which are not American, is by 'playing the anti-Semitic card'. This has been a contrived defence strategy that has stunted any serious debate.

Mearsheimer and Walt's book has finally allowed the issue to be addressed academically rather than at the margins of society. Additionally, the stature of its authors has allowed for much deeper and wider debate than has been the case previously. The Israel lobby thesis visits, yet dismisses, the importance of other lobby interests in the future of the Middle East, such as the oil lobby and the arms industry, which comes across as premature. Yet despite the apparent flaws, dismissing the thesis out of hand as Commentary predictably wishes, is a missed opportunity when attempting to understand the full scope of how American policy is forged towards the Middle East. This is especially the case when observing the strikingly similar rhetoric of both Israel's senior political figures and the American neoconservatives, most notably regarding Iran.

\footnotetext{
${ }^{4}$ For more on this see: http://www.foreignpolicy.com/articles/2009/12/04/iran_is_no existential threat.

${ }^{5}$ http://www.cbsnews.com/stories/2010/04/14/world/main6395688.shtml.
} 


\section{CONTINUITY OR CHANGE?}

With a new President in office as of January 2009, Barak Obama and his administration have demonstrated a clear desire to distinguish themselves from their predecessors. However, the fact remains that the wars in Iraq and Afghanistan have continued - escalated in some senses - and rhetoric on Iran, for example, has progressively hardened despite the early offer of constructive dialogue with Iran. It may be fair to ask whether there is much difference in practical terms between the Bush and Obama pursuit of Middle Eastern policy. Whether or not this can be attributed to a continued active neoconservative influence in the Obama administration is doubtful. However, considering the Obama administration inherited such deep foreign policy baggage and American military entrenchment in this part of the world, a course reversal would be much more extreme than a tacit continuation of the general thrust of the previous approach. The decision to keep Robert Gates in the Pentagon is certainly an indication of this intent. Whist Obama is clearly not of the neoconservative persuasion, he certainly seems to be tacitly sympathetic to the broad logic of the Bush approach in the Middle East, or at the very least cognisant that dramatic change would be more disastrous politically than continuation.

Maintained support for the ongoing policy of democratisation in the Middle East may prove to be the glue between the two administrations, though in a clear semantic break Obama has steered clear of trumpeting the power of democracy as Bush frequently did, preferring to use terms such as 'freedom' and 'development' in his public rhetoric (Bouchet 2010). This is clearly a break in semantics, though not in policy, similar to Obama's jettisoning of the term 'War on Terror', as both the War on Terror and the American democratisation project in the Middle East are evidently continuing apace.

It is an often observed trend in international politics that foreign policy rarely dramatically changes; rather it slowly evolves. President Truman famously declared that he saw foreign policy as residing above the partisan divide. In American politics and the politics of national security, his words have indeed proven largely accurate. A standard example given by historians is the continuation of bipartisan American involvement the Vietnam War across five administrations between 1959 and 1975. To take the analysis of continuity deeper, many designate Ronald Reagan (an icon for the neoconservatives) for the ramping up of American military spending and overturning the decline in strength witnessed in the detente era, which in turn led to the eventual economic strangulation of the Soviet Union as it failed to keep up. In truth, this process was initiated by Jimmy Carter in 1979-1980. He was infuriated by the revolution in Iran and the Soviet invasion of Afghanistan. Reagan simply rode the wave and carried it forward, and belatedly took credit. Similarly, many attribute Richard Nixon for creating the 'twin pillar' strategy of fortifying the Middle East by building up Saudi Arabia, and especially Iran, via advanced weaponry sales and military training. This was used to act as a buffer for the southward spread of the Soviet Union when the British declared they would withdraw their security blanket from the Persian Gulf by 1971. Yet, this process was already in motion in the final years of the Johnson administration, and it was more accurately a strategy devised and promoted by the Shah of Iran as early as $1965^{6}$, not by the Nixon administration. One final example was in the Eisenhower sanctioned CIA/ British SIS coup in Iran in 1953 which reinstated the Shah as ruler of Iran, overthrowing the democratically elected nationalist leader, Mohammad Mosaddegh. Many have attributed this

\footnotetext{
${ }^{6}$ See: Telegram from the Embassy in Iran to State. Tehran, December 29, 1965. Foreign Relations of the United States, 1964-68, Vol. XXII, Iran.
} 
decision to the change in President, Eisenhower having replaced Truman, and he was widely regarded as leading a much more aggressive administration. However, careful examination of the declassified papers revealed that Truman had significant CIA assets and operations active in Iran, suggesting much more of a continuity than a change in policy (Marsh 2005).

Therefore it is often easy to accredit policy changes to a change in leader, but this is rarely accurate, and defies the momentum that foreign policy has across administrations and across the partisan divide. All previously given examples highlight not only changes in administration, but changes in governing party from Democrat to Republican, highlighting the comparative ease with which a certain foreign policy course can override standard partisanship. In Obama's case, he inherited a foreign policy momentum in the Middle East that he has chosen to see through, rather than halt. There have been changes in language and posture, such as the careful jettisoning of the term 'War on Terror', yet the general thrust of the Bush legacy in the region remains intact, in what is surely a bitter pill to swallow for all those who voted for 'change' in November 2008. Nowhere can this be more visible than in the case of Iran as it continues to approach full mastery of the nuclear cycle in defiance of steadfast American and Israeli wishes.

The Iranian President, Mahmoud Ahmadinejad, recently noted that America under Obama had not changed from the America of Bush in its foreign policy application in the Middle East. Obama has not closed Guantanamo Bay despite promising to do so, has not altered American refusal to countenance a truly independent Iranian 'civilian' nuclear program, and he has not changed course in Afghanistan or in Iraq. Similarly, unconditional support for Israel - the frequent demon in Iranian domestic discourse regarding America, has been broadly retained, though with some qualifications. Such statements are of course true, despite their unpopular source. Cutting through the friendly appearance and conciliatory rhetoric of the Obama administration, the Nobel Peace Prize award, and considering its refusal to use the term 'War on Terror' does not detract from the reality that regarding foreign policy towards the Middle East, nothing of substance has indeed changed. The fact that arguably the world's most notorious 'elected' statesman has pointed towards this elephant in the room does not mean that it should be ignored.

The PerseVerance of THe Persuasion

Neoconservatism did not accurately perceive American military power, the power of democratisation, or the failure of the world's population to accept its ideological persuasion in the midst of convincing evidence to the contrary, particularly as things turned sour in Iraq. It seems that far from playing the final act in the end of history, the neoconservative persuasion has caused a crisis of legitimacy in the global system. American power is no longer seen as legitimate by many, and the jury is still very much out on whether the wave of euphoria circulating around the election of Obama has actually gained any long term traction in repairing the damage. The United Nations' normative and legal power base was dealt a serious blow by the Iraq invasion, and Iran did not follow the democratic domino course, leading to a popular fear that American actions in the Middle East will actually ignite a clash of civilisations.

That being said, perhaps surprisingly, the Obama administration is broadly continuing the Bush, neoconservative inspired, legacy in the Middle East, despite its more multilateral and diplomatic persona in international politics and its desire to be viewed as clearly 
different from its predecessor. The neoconservative persuasion may not have fared well in the broad ideological sense, but its general approach as demonstrated in the implementation of policy application may have fared better. Neoconservatism's approach of democratising the Middle East via military intervention, tempering terrorism in the area, and dealing with Iran decisively has already formed the core of Obama's policy package - all continuations from the Bush administration. Barely anything of significance has changed in a practical sense, and the continued standoff over Iran's nuclear proliferation has highlighted this for all to see. Barak Obama may have started out intending to pursue a different regional strategy than that of George W. Bush, as displayed most clearly in his early dealings with Iran. Nonetheless, predictable belligerence and brinkmanship from Iran over continuation of its nuclear programme has quickly resulted in the new President having to withdraw his invitation to enter into a constructive dialogue and resorting to an approach indistinguishable from the one carried by the Bush administration.

Obama is not a neoconservative; but history may, perhaps surprisingly, record his actions in broadly continuing the logic of the 'War on Terror' (albeit by another name) and the continuation of the neoconservative plan for the Middle East.

\section{REFERENCES}

Bouchet, N. 2010. "Barack Obama's Democracy Promotion After One Year.” e-International Relations. http://www.e-ir.info/?p=3300.

Bloom, A. 1987. The Closing of the American Mind. New York: Simon and Schuster.

Brzezinski, Z. 2007. Second Chance: Three Presidents and the Crisis of American Superpower. New York: Basic Books.

Bush, G.W. 2002. Graduation Speech at West Point.

http://www.whitehouse.gov/news/releases/2002/06/20020601-3.html.

Chomsky, N. 2003. Hegemony or Survival: America's Quest for Global Dominance. London: Penguin.

Frum, D. 2003. The Right Man: An Inside Account of the Surprise Presidency of George W. Bush. London: Weidenfeld and Nicolson.

Fukuyama, F. 1989. "The End of History?" The National Interest Summer 1989. http://www.marion.ohio-state.edu/fac/vsteffel/web597/Fukuyama history.pdf.

Fukuyama F. 2006. After the Neocons: America at the Crossroads, London: Profile.

Gorenberg, G. 2008. "Israel.” Foreign Policy May/June 2008: 26-32.

Huntington, S. P. 1997. The Clash of Civilizations and the Remaking of World Order. London: Simon and Schuster.

Ikenberry, G. J. 2001. “American Grand Strategy in the Age of Terror.” Survival 43(4): 19-34.

Ikenberry, G. J. 2002. "The Lures of Preemption." Foreign Affairs 81(5): 44-60.

Ikenberry, G. J. 2004. “The End of the Neo-Conservative Moment.” Survival 46(1): 7-22.

Kagan, R. and Kristol, W. 2000. "National Interest and Global Responsibility." In Present Dangers: Crisis and Opportunity in American Foreign and Defense Policy, eds. Kagan, R. and Kristol, W. San Francisco: Encounter Books: 1-24. 
Kagan, R. 2002. “One Year After: A Grand Strategy for the West?” Survival 44(4): pp. 135156.

Krauthammer, C. 1990. “The Unipolar Moment.” Foreign Affairs 70(1): 23-33.

Kristol, I. 1995. Neoconservatism: The Autobiography of an Idea. Chicago: Elephant.

Kristol, I. 2003. “The Neoconservative Persuasion.” The Weekly Standard 2008(47): 1-3.

Lewis, B. 2004. From Babel to Dragomans: Interpreting the Middle East. London: Weidenfeld and Nicolson.

Lind, M. 2006. "The Alternative to Empire" Prospect. http://www.prospect.org/cs/articles?articleId=12098.

Marsh, S. 2005. "Continuity and Change: Reinterpreting the Policies of the Truman and Eisenhower Administrations toward Iran, 1950-1954." Journal of Cold War Studies 7:3 (Summer 2005): 79-123.

Mead, W.R. 2006. “God's Country?” Foreign Affairs 85(5): 24-43.

Mearsheimer, J. 2005. "Hans Morgenthau and the Iraq War: realism versus neoconservatism”. London: OpenDemocracy.

http://www.opendemocracy.net/democracy-americanpower/morgenthau 2522.jsp

Mearsheimer, J.J. \& Walt, S.M. 2007. The Israel Lobby and U.S. Foreign Policy. London: Penguin.

McFaul, M. 2004. "Democracy Promotion as a World Value." The Washington Quarterly 28(1): $147-163$.

Murray, D. 2005. Neoconservatism: Why we need it. London: The Social Affairs Unit.

Perle, R. 1999. "Iraq: Saddam Unbound." In Present Dangers: Crisis and Opportunity in American Foreign and Defense Policy, eds. Kagan, R. and Kristol, W. San Francisco: Encounter Books: 99-110.

Podhoretz, N. 2006. "Is the Bush Doctrine Dead?" Opinion Journal [online]. http://www.opinionjournal.com/federation/feature/?id=110008830.

Podhoretz, N. 2007. "The Case for Bombing Iran.” Commentary Magazine [online]: http://www.commentarymagazine.com/viewarticle.cfm/The-Case-for-Bombing-Iran$\underline{10882}$.

Stephens, B. 2007. “The Israel Lobby and U.S. Foreign Policy” Commentary 124(4): 73-78.

The National Security Strategy of the United States of America September 2002 [online]. http://www.whitehouse.gov/nsc/nss.html.

The National Security Strategy of the United States of America March 2006 [online]. http://www.whitehouse.gov/nsc/nss/2006/. 